\title{
The San values of conflict prevention and avoidance in Platfontein
}

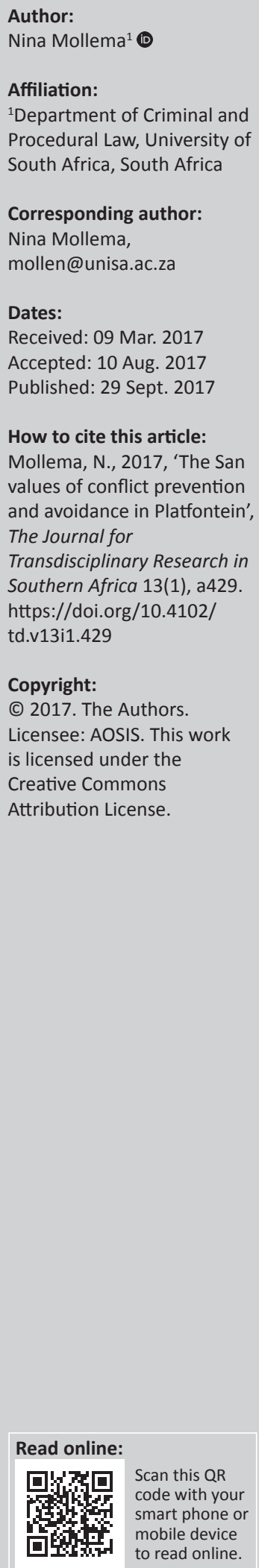

\begin{abstract}
The aim of this article is to identify measures that can prevent violent conflict through the maintenance of traditional cultural values that guide conflict avoidance. Moreover, the article focuses on the concepts of conflict prevention and conflict avoidance as applied by the San community of Platfontein. The causes of the inter-communal tensions between the San community members are also examined. A selected conflict situation, that of superstition and witchcraft, is assessed as factors increasing interpersonal conflict in the Platfontein community. This investigation is made to determine if the San preventive measures have an impact in the community, so as to prevent ongoing conflicts from escalating further.
\end{abstract}

\section{Introduction}

The San of Southern Africa have experienced colonial oppression, dispossession of their traditional lands, displacement and systemic violence over the past hundreds of years (see Adhikari 2010; Velthuizen 2010). Although their human rights have been violated throughout Southern African history, the San have in the past been idealised by scholars such as Lee (1979) and Vorster (1996) as peace-loving and harmless communities. ${ }^{1}$ In their traditional settlement areas, disputes surrounding land and natural resources seldom produced any conflict (Lee 1979:370). However, conflict still exists which in certain cases may lead to serious injuries and death. ${ }^{2}$ Generally, the San avoid any type of conflict by applying appropriate conflict prevention methods before any clashes may erupt. This is evident from interviews conducted in Platfontein, where it has emerged that, amongst other causes, conflict is currently generated in the community by fear of alleged practices of witchcraft. ${ }^{3}$ Malicious magic is blamed for misfortunes such as disease, sudden death and any type of calamity. The overarching purpose of the article is to determine if the traditional San preventive measures have an impact in Platfontein, so as to diffuse these types of imminent conflict situations and to forestall ongoing conflicts from escalating further. In this context, the article first considers the concept of conflict as well as the key components of effective conflict prevention and avoidance strategies; secondly, it critically assesses the conflict prevention and avoidance capacities of the Platfontein San as regards witchcraft and, finally, customary approaches to deal with and improve the current conflict situation in the community are presented. In order to effectively prevent, manage, and resolve conflict in the community, pre-existing preventative measures must be strengthened and adhered to, but new mechanisms must also be instituted and developed.

\section{Background to conflict prevention and conflict avoidance}

Throughout human history, people have been exploring ways to prevent conflicts; however, the term was rarely used explicitly and people did not necessarily see their actions as preventive. For conflict prevention measures to be initiated, the perception of a threat or actual

1.See also Isaacson (2001). Some authors have suggested that Lee has simplified the situation; see, for example, Boehm (2000) who identified 'pre-contact' conflict-ridden patterns common to all hunter-gatherer groups. Fry (2007) again differentiates between simple,
nomadic hunter-gatherers (NHGs) and complex hunter-gatherers (CHGs), and asserts that while in NHGs war is rare, it is common in CHGs. He draws a causative link between settled living (as copious food resources allow CHGs to settle down) and war. Boehm (2000:81) CHGs. He draws a causative link between settled living (as copious food resources allow CHGs to settle down) and war. Boehm (2000.
further maintains that 'so long as they remain mobile - rather than sedentary - they are remarkably uniform in their social, moral, and political makeup'. He adds that these bands are moralistic 'for they practice sanctioning according to established values that assist in identifying deviants' and that 'they suppress undue competition, and head off attempts of individuals to exert domination or control; as a result, they tolerate very little leadership'.

2.Reasons for inter-personal conflict have mostly been different viewpoints, unfair distribution of meat or exchange of gifts, laziness and accusations of adultery (see Lee 1979:372).

3.R. Dakane, Dakane Oral Archive (DOA), Interview with J.A., Block: N/A, Platfontein, 26 May 2014: 'The people are jealous of other people's possessions. They practice witchcraft/put spells on one another and they do wrong things'. Witchcraft and sorcery are used interchangeably in this article, although some researchers of African societies differentiate between these two terms - witchcraft is seen as the use of black magic by women born with this ability, while sorcery may be learned and practised by anyone. See also Hammond-Tooke (1989). This sensitive subject seems always to be relegated to footnotes as Barnard (2007) observes:

On the other hand, concern with the specific, such as the question of ... witchcraft among Bushmen, would end up as footnotes in the works of scholars within Bushman studies. (p. 96) 
occurrence of conflict is necessary. It is as such essential to briefly address the concept of conflict before exploring possible approaches to prevent or avoid such occurrences. Traditionally, conflict is the result of opposing interests involving scarce resources, goal divergence and frustration. This may not only include violence (behaviour) or hostility (attitudes), but also incompatibility or differences in issue position (Swanström \& Weissmann 2005:7). Drivers of conflict are primarily identity and values. Conflicts may be caused by substantive drivers such as territory, resources, economy or politics and identity drivers, group memberships such as ethnicity, culture, ${ }^{4}$ tribe, race or religion. All conflicts seem to involve interplay between both kinds of drivers. It is important to note that conflict per se is not always undesirable; conflict may have positive consequences such as transformation and growth. However, resolving conflict through violence is destructive and does not lead to viable and lasting solutions.

The study of the concept of conflict prevention has a relatively short academic history, yet there is a vast amount of literature on the subject (Swanström \& Weissmann 2005:19). Although commonly practised by all parties concerned, there is generally a lack of consensus and diverging interpretations of the concept. The term suggests different things to different people and there is no approved meaning amongst scholars, as seen from the examples below:

The application of non-constraining measures (those that are not coercive and depend on the goodwill of the parties involved), primarily diplomatic in nature. (Munuera 1994:3)

The aim of preventive action is to prevent the emergence of violent conflict, prevent on-going conflicts from spreading and prevent the re-emergence of violence. (Carnegie Commission on Preventing Deadly Conflict 1997:xviii)

A medium and long-term proactive operational or structural strategy undertaken by a variety of actors, intended to identify and create the enabling conditions for a stable and more predictable international security environment. (Carment \& Schnabel 2003:11).

On a general level, conflict prevention is a broad term for 'methods and mechanisms used to avoid, minimise and manage potential conflicts [between different parties] before they have developed into active conflicts' (Swanström \& Weissmann 2005:5). As all conflicts are context-specific, conflict prevention requires the identification of conflict dynamics such as the causes, possible escalation and sustainability of the conflict. As such, effective conflict-prevention strategies will entail a conflict analysis where deficiencies in the current situation are identified and addressed before any possible outbreak of violence to ensure a desired future. Conflict prevention is closely related to conflict management, which focuses on the limitation, mitigation and containment of a conflict without necessarily solving it (Tanner 2000:541). These

4.To elucidate the values and norms by which the San live by, the term culture is defined as:

a set of distinctive, spiritual and material, intellectual and emotional characteristics, which define a society or social group. In addition to the arts and letters, it encompasses ways of life, the fundamental rights of the person, value systems, traditions and beliefs. (see UNESCO 1982:1) two concepts are in many ways inseparable, having overlapping and integrated aspects.

Conflict prevention may be sectioned into two main categories: direct and structural prevention. Direct prevention attempts to avert the impending escalation of a potential conflict in the short term, while structural prevention addresses factors which may likely cause conflict in the long term. Following Lund's definition of conflict prevention (Lund 2002:117), the concept will, in this article, include any structural means to:

- prevent internal disputes and strains from increasing into substantial violence

- reinforce the competencies of parties involved in a potentially violent conflict situation to settle their differences peacefully

- gradually diminish the underlying causes of such disputes and tensions.

Conflict avoidance, in contrast, is a strategy wherein an attempt is made to indefinitely defer or directly evade the imminent conflict. The reasoning behind avoidance is the prospect that the conflict may resolve itself without any confrontation occurring. This may be accomplished in a variety of ways, for example issue avoidance, person avoidance or mere passivity, amongst others. However, this method seems to be suitable more as a temporary measure as the issue causing conflict is not directly dealt with. Conflict avoidance can also take the form of withdrawal (Swanström \& Weissmann 2005:19). Terminating an impaired relationship when parties cannot resolve a potential conflict may, in certain situations, be a sounder option. Thus, avoidance strategies can produce outcomes where one party has benefitted from the process but the other has not, or where none of the parties perceive the result as positive, or even where both parties have gained from the resolution. It is preferable that parties in a potential conflict settle their differences so as to satisfy mutual interests. This may entail that a new solution than originally acquiesced will have to be found, a possibility that the Platfontein San should consider in their specific conflict scenarios.

\section{Methodology}

This article is informed by the research results from the San Dispute Resolution Community-Based Participatory Research (CBPR) project. This participatory project aimed at engaging the San community as active contributors in research, wherein they provide their own perceptions on local conflict situations. In this manner, they pursue their own solutions according to their specific priorities. As such, the participatory research methodology utilised emphasises a 'bottom-up' approach where San indigenous knowledge and perspectives are explored.

The data for the research project were collated by trained Platfontein San field researchers. The field researchers were selected considering their multilingual abilities (they needed to read and write English, Afrikaans and either 
!Kun or Kwedam to access the knowledge of especially knowledge holders who could not speak any modern language). Equity was also a consideration: four men and four women were chosen. The individuals were nominated by the Community Property Association of Platfontein who appointed a coordinator, who took responsibility for general conduct. Bias was mitigated by ensuring that a broad spectrum of knowledge holders in terms of gender, age and clan could be reached, reducing the influence of dominant narratives of a few. The project leader, Dr Velthuizen, taught the field researchers the basics of field research including interviews, focus group facilitation, report writing, capturing with cameras and voice recorders, administration concerning individual informed consent and ethical conduct.

The field researchers interviewed the San community and community leaders on selected conflict issues. In this manner, more than 250 interviews, focus group and interpretation discussions were conducted from 2013 to $2015 .{ }^{5}$ From these interviews and discussion, the researcher was able to make use of only 14 interviews where the theme of witchcraft was specifically discussed. Data collection further took place by means of field visits to the !Xun and \$Khomani San settlements of Platfontein and Andriesvale, respectively, where participant observation as well as a workshop were undertaken. Further personal unstructured and semistructured interviews with two respondents were completed. An extensive review of the secondary literature and official documentation on the situation of the Platfontein San was also conducted to inform the collated data. The information gained from the interviews was interpreted with the assistance of key knowledge holders and field researchers from the San community who assisted with the breakdown and critical reflection of the data. ${ }^{6}$

\section{Inter-communal conflict amongst the Platfontein San community}

Originally from Angola, the San have been transplanted to Namibia and South Africa, which has led to their way of life, values and beliefs being transformed (Velthuizen 2010: 28-29). The resettlement of two mostly unrelated groups of San to a more sedentary life, who now have to share a far smaller area, has brought new challenges. Originally microcommunities living as highly mobile nuclear family groups, the various San clans used to have enough land to sustain their family groups, while being able to respect territorial borders and avoid conflict with neighbours. On Platfontein the San feel trapped, boxed in by the borders of surrounding farms. People cannot walk far enough to gather sufficient firewood or veld food, let alone hunt and crossing over onto neighbouring farms means dealing with irate farmers. There are also intense inter-communal tensions between the two resident groups of !Xun and Khwe.

5. This information is stored online as the San Dispute Resolution Oral Archive available at http://uir.unisa.ac.za/handle/10500/13723. Also see Velthuizen (2010:30-31).

6.See Velthuizen (2010:31). This occurred mainly at a writers' retreat workshop held in August 2014.
To trace these tensions, one must examine the history of these groups. The !Xun (Vasequela) and Khwe (Baraquena) are two very different groups of people with a complex history of division and segregation (Robins, Madzudzo \& Brenzinger 2001:9). Both !Xun and Khwe regard themselves, and are considered by others, as San, but they understand themselves to have very different geographical origins, histories and traditions (see H. Sibongo, Sibongo Oral Archive (SOA), Interview with K.M., Block: Morosani, Platfontein, 22 May 2014.; Soskolne 2007). It is believed that the !Xun originally came from central Angola around Serpa Pinta (however, opinion is divided over whether the !Xun were originally from Angola, or if they had migrated up north from Namibia and Botswana), while the Khwe were mainly from south-east Angola and Zambia, centred around Eastern Caprivi (Robins et al. 2001:8). The Khwe have been described as 'black bushmen' (Uys 2014:7-8) because of their relatively tall stature and darker skin, in comparison with the !Xun's lighter skin and small stature. This ethnic, social and cultural separation is also visible in the settlements as the !Xun and Khwe requested two spatially divided farms at Platfontein, but were not granted this because of insufficient funds (Robins et al. 2001:9).

The Platfontein community is divided and ravaged by deep distrust between the two groups. ${ }^{7}$ Jealousy may play a factor here. When the San were employed by the South African Defence Force (SADF) at the Omega military base, the Khwe were regarded as more powerful: 'There was apparently quite a bit of status involved with being Khwe's (Robins et al. 2001:21). The !Xun are, however, the majority population in Platfontein, a power shift which may be uncomfortable for the Khwe. ${ }^{9}$ The first conflicts that took place between these two groups also occurred at Omega in the 1970s (Vorster 1994:72). ${ }^{10}$ A dispute started, for instance, when an intermarriage occurred between a Khwe woman and a !Xun man. The young men of these two groups fought for almost two days about the discord. ${ }^{11}$

7.Many interviews refer to the lack of trust between the groups. See, for example, DOA, Interview with K.C., Block: N/A, Platfontein (22 May 2014):

There are two communities here but we are different. We don't speak the same language and we don't trust one another. The result of the huge problems the San community experience was that they didn't live together in olden times. There were different villages and each village had a tribal leader.

The community is also physically divided as both the !Xun and the Khwe occupy opposite ends of the Platfontein farm.

8.The opinion of Roger Chennells from the South African San Institute (SASI) is quoted here. Chennels further maintains that while in the SADF, the Khwe were in the majority; however the accuracy of this statement cannot be verified.

9.There are currently approximately 4500 !Xun and 2500 Khwe inhabitants in Platfontein (see Beyene 2014:100)

10.Conflict may also have been initiated by the differential treatment by the SADF of the two groups. According to Sharp and Douglas (1996:325-326), the SADF tended to provide greater assistance to the Khwe because of their perceived military value. They were regarded as 'the ideal warrior - combining the strength of the black with the cunning of the Bushman' according to Uys (2014:10). See also Hitchcock (2012) for further evidence of intra-group tensions.

11.Although the San do not frequently marry outside their own ethnic group, intermarriages do occur. See N. Mollema, Mollema Oral Archive (MOA), Interview with M.M., Block: Kamatoka, Platfontein, 08 August 2014 and Becker (2003:21). There are also inter-ethnic non-marriage liaisons, but as will be illustrated, if the There are also inter-ethnic non-marriage
liaison results in a teenage pregnancy:

more often than not a boyfriend does not acknowledge paternity and in any event does not provide for the child, in particular if he is from a different ethnic group.

See Felton and Becker (2001:41); see also MOA, Interview with M.M., Block: Kamatoka, Platfontein, 08 August 2014, who maintains that 'Baie van die Khwe mense trou met ons meisiekinders, nie eintlik trou nie, hulle mors met hulle eintlik. 
It was also at Omega where suspicions were raised that certain persons were dabbling in the dark arts, ${ }^{12}$ as confirmed in S $v$ Mathoka and Others 1992 (2) SACR 443 (NC) 445. In this case, the deceased, who relocated from Angola to Namibia with the San group, was known to the community as a wizard who used black magic to kill people in Angola as well as in northern Namibia. In Omega, an alleged witchcraft-killing caused by this man was reported to the SADF officers; however, when nothing was done to solve the problem, the San chose to tend to these types of matters themselves (see Mathoka case).

\section{Witchcraft as a factor increasing conflict in the Platfontein community}

Although most traditional San believe in a 'Greater' and a 'Lesser' Supreme Being or God (Guenther 1999:61-62) as well as other supernatural beings and the spirits of the dead, the practice of witchcraft - that is, the manipulation by malicious individuals of supernatural powers and magic materials to kill or cause harm to others - is not encountered in all these hunting-gathering societies. The two San groups at Platfontein are a suitable illustrative case. One group (Khwe) make use of shamans, while the other group (!Xun) does not. ${ }^{13}$ The !Xun San state unequivocally that witchcraft is 'not a Bushman thing' and that witchcraft should not be practised in their community (Vorster 1994:77). ${ }^{14}$ This is also confirmed by literature on this society (Guenther 1992:91, 1999:88). Historical research on the Khwe has shown that shamanism was acquired mainly by means of acculturation with African tribes (Köhler 1978/1979:11-12). ${ }^{15}$ According to these studies, shamanism is quite specialised amongst the traditional Khwe and includes such ritual actions as divination, hunting magic, and an extensive complex of pharmaceutical and shamanic curing techniques. Research has, however, revealed that evil shamans or sorcerers, while well-defined socially within Khwe culture and folk

\section{(footnote 11 continues..)}

Hulle maak kinders, twee, drie kinders, dan los hulle daardie vrou en dan moet ons daai kind grootmaak, en as daai kind groot is, hy is Khwe, hy is nou nie meer ons kind nie (Many Khwe men marry our girls, no, not actually marry, they mess with them. They have children, two, three children, then they leave the woman and we have to raise that child, and when the child is grown, he is Khwe, he is no longer our child)'.

12.N. Mollema, Mollema Oral Archive (MOA), Interview with M.M., Block: Kamatoka, Platfontein, 08 August 2014 where it was stated that there were persons 'living with magic items on their bodies'.

13.Shamans include both medicine specialists (traditional specialists who heal with herbs and roots) and diviners (soothsayers who diagnose the cause of illnesses) See Guenther (1999:88-89), Vorster (1994:77) and H. Sibongo, Sibongo Ora Archive (SOA), Interview with O.N. Block: Morosani, Platfontein, 28 March 2014:

Currently here in Platfontein they are still practicing, and they do good, most of us use to visit them because in the past our elders use to believe in them because they as the traditional healers and for husband and are alone, to talk about it then he/she have to see the specialist.

H. Sibongo, Sibongo Oral Archive (SOA), Interview with M.K., Block: Kamatoka, Platfontein, 16 March 2014: 'there were also traditional healers who have dreams about what's going to happen tomorrow'. The problem is that shamans may turn towards evil, employing either the services of malicious spirit familiars or mystical or outright poisons to harm their victims, and thus become a sorcerer.

14.Brain (1982:380) argues that sedentary communties tend to engage in witchcraft.

15.Robins et al. (2001:4) notes that circa 1800 the Mbukushu tribe migrated southwards where they enslaved and forcefully intermarried with Khwe in Namibia/Botswana. imagination, are relatively rare 'on the ground'. ${ }^{16}$ This also holds true for the contemporary society as none of the San will admit that witchcraft is practised by them - it is a clandestine subject. ${ }^{17}$

As a result of co-residence within the same farm, the !Xun and the Khwe have been drawn within the cultural matrix of the other. The San's loss of mobility and collective settlement has not only resulted in acculturation, but also in their economic dependency for survival - firstly, on the SADF and, currently, mainly on government grants - and led to loss of egalitarianism, individual autonomy, language and traditional tutelage. The community further displays elements of social disintegration with prevailing group tensions, unemployment, poverty, and health and service delivery concerns. It has been discerned that 'witchcraft superstition seemingly flourishes in times of social instability' (Parrinder 1963:205). ${ }^{18}$ Thus, whenever an episode of conflict involves the transmission of harm through supernatural means, the one group tends, in terms of their perception, to be at the receiving end of witchcraft, as its victims, not as its transmitters. Traditionally, the San rarely attribute illness or death to the evil intent of another person (Shostak 1981:212). However, at Platfontein, cases of interpersonal conflict were expressed socially in the idiom of witchcraft. This expression ranged from suspicions and accusations through rumours, to outright accusations, and these actions could either involve only an individual, his or her close relatives or neighbours, or they could be amongst all members of the community.

Witchcraft accusations are seen by some scholars to reflect the underlying tensions in a community, which may serve various functions. Allegations may act as a vent for repressed social anxieties in order to readjust social relationships (Evans-Pritchard 1976:xxi-xxiii). As such, an upsurge in witchcraft accusations indicates the moral breakdown of that community (Gluckman 2012:241). Witchcraft blame-pinning may fulfil the purpose of terminating unwanted social relations (Marwick 1982:64), or may even be employed to intimidate the opposition (Steadman 1985:115). It may be asserted that all of these functions feature to various extents amongst the Platfontein San. Witchcraft-related conflict issues in the community range from unexplained, sudden, and 'bad deaths', rivalry for authority, failure to pay money,

16.See, for example, Tebbe (2007:190): 'sorcery is thought to be practiced in secret ... witchcraft is not a faith that people openly profess. Rather, it is a second-order term of accusation or suspicion'.

17.In S v Mathoka (1992:448), Judge Kriek expresses this as such: 'Van toe af is swart magie by hulle ' $n$ werklikheid waarmee rekening gehou moet word, maar waaroor daar nie graag gepraat word nie, want as jy daaroor praat roep jy dit (Since that time black magic became a reality which has to be taken into account, but which is not spoken about, because if you talk about it, you call it)'.

18.Brain (1982:378-379) identifies the policy of villagisation (forced movement into villages) in Tanzania as the main factor contributing to fear as regards witchcraft. He avers that suppression of anger results in feelings of depression which inevitably He avers that suppression of anger results in feelings of depression which inevitably ultimately death. Communities forced to live close together deal with their fears ultimately death. Communities forced to live close together de

erupt in conditions of social and economic change, uncertainty and insecurity, poor nutrition and health facilities, and when people feel that traditiona practitioners like waganga are inadequate to cope with present difficulties.

Although Brain's hypothesis corresponds to the situation of the Platfontein community, there has not been any evidence as yet of witch-finding movements. 
domestic quarrels between spouses or school children, refusal to accept sexual advances, retaliation for a wrong suffered and, the classic issue, envy over another person's good fortune (Guenther 1992:84).

In all identified cases of witchcraft accusations or speculations, the belief is held that misfortune and suffering are signs of the act of invisible and malevolent power. Sorcerers have the capacity to utilise any agent or means to achieve this purpose. Common instruments employed to inflict sufferings are magic potions (usually kept in pots) ${ }_{1}^{19}$ dreams, ${ }^{20}$ mirrors ${ }^{21}$ or familiars such as cats and chickens (Ashforth 2000:188). ${ }^{22}$ The belief amongst the Platfontein San is not only that there are sorcery specialists in the community, but also that every individual is a potential sorcerer or witch, depending either on a person's incidence of quarrelling with others or on the extent of envy and desire. Even neighbours, relatives or school children can utilise bad magic (Ashforth 2000:5). ${ }^{23}$ It is purported that many men extort girls into having sexual relations by threatening them with the consequences of witchcraft. The girls bear children with these men whereafter the mother and children are abandoned, leaving the girl's family to raise the children. ${ }^{24}$

There is especially amongst the San communities a fear that their culture and their values will be swallowed up as a community subjected to mandatory merging. The !Xun especially do not want their group members to acquire patterns of witchcraft as a result of acculturative contact and conflict. As such, any use of occult powers is forbidden. An incident that occurred at Schmidtsdrift illustrates this well (N. Mollema, Mollema Oral Archive (MOA), Interview with M.M., Block: Kamatoka, Platfontein, 08 August 2014). After discovering that his wife had extra-marital relations, the husband warned his spouse with the ill-fated forewarning: 'You will see'. ${ }^{25}$ Not long thereafter, the pregnant woman

19.See Ashorth (2000:160). A huge, consistently-boiling pot filled with magical concoctions emanating deadly smoke is blamed for the many illnesses and deaths in the Platfontein community. See also N. Mollema, Mollema Oral Archive (MOA) Interview with M.M., Block: Kamatoka, Platfontein, 08 August 2014. It is also deemed one of the reasons why so many youths commit suicide - suicide is seen a result of witchcraft. See Oatway (2013).

20.Ashforth (2000:208) and Vorster (1994:78). A familiar that appears in one's dreams is sent by the sorcerer as a warning that one will become ill. Dreaming of a familia allegedly caused the legs of a Platfontein man to swell up so that he had to make use of crutches in order to walk (see N. Mollema, Mollema Oral Archive (MOA) Interview with M.M., Block: Kamatoka, Platfontein, 08 August 2014).

21. In S v Mathoka, the alleged sorcerer had a piece of mirror in his medicine bag. He placed medicine on this mirror to summon familiars to haunt people in their dreams (see Vorster 1994:78). Shamans also make use of mirrors in order to identify the cause of the illness or misfortune.

22.It is asserted that a chicken, treated with magic medicine, was roaming the community, spreading disease. If the chicken pecked a person, that person would die (see N. Mollema, Mollema Oral Archive (MOA), Interview with M.M., Block: Kamatoka, Platfontein, 08 August 2014).

23.For example, knowledge (during times of assessment) may be transferred from one pupil to another by means of magic spells. This may be countered by the use of sea water, an antidote against evil charms (see N. Mollema, Mollema Ora Archive (MOA), Interview with O.M., Block: Kamatoka, Platfontein, 08 August 2014). The so-called 'salt-churches' (Apostolic Church in Zion) present in Platfontein also make use of salt as cleansing agent (see Vorster 1994:72).

24.According to Felton and Becker (2001:50): '!Xu girls were said to be impregnated by Khwe men, who later took no responsibility for either the young mother or the child'. Threats of sorcery are accordingly blamed for engaging in early sexual relationships and the resultant high number of teenage pregnancies.

25.This threat, that is, 'you will see death', seems to be the standard warning in case of witchcraft-related accusations in this community (see Vorster 1994:75). experienced problems and died within a few hours. After a traditional hearing, the husband was found guilty of causing a witchcraft-related death and sentenced to death. The family and community were particularly infuriated by the man's usage of sorcery. This counter-killing was not a revenge-induced action of vindictiveness but an act of 'self-help', intended to rid the community of a dangerous agitator. $^{26}$

As 'every evil and misfortune that is incapable of rational explanation is attributed to witchcraft' (Mutungi 1977:105), afflicted persons seek out traditional healers and diviners to determine the source of the misfortune. These shamans are regarded as having occult power capable of curing and protecting one from evil. The desired result is not always achieved, ${ }^{27}$ as in the case where a Khwe man's foot had to be amputated because of alleged bewitchment. Despite receiving medical attention and being hospitalised for a period of 18 months, the man's condition deteriorated. Convinced that the malevolent hex could only be repelled by powerful shamans, the man visited a traditional healer; however, without any success (Vorster 1996:10).

When conventional and traditional remedies fail, the source of the illness must be identified in order to induce them 'to retract their evil powers, and [be] punished (or cleansed and redeemed)' (Ashforth 2001:6). This traditional manner in dealing with a witch is exemplified in the only witchcraft case concerning the San, that of $S v$ Mathoka. In this case, a San man who had been proved to be by repute a witchdoctor allegedly caused the death of a corporal's mother in December 1991. All the community's attempts to bring him to book failed. The man subsequently threatened one of the accused persons that he would soon die. When the threatened person's wife died while in childbirth the following day, the man was confronted by the accused. He admitted that he had caused the woman's death. He was requested to hand over his black magic paraphernalia in order for it to be destroyed either by being thrown into a stagnant river or by being burnt in front of the community. ${ }^{28}$ The man surrendered some items; however, it was believed that not everything was submitted. This was acknowledged; still the man persistently refused to hand the rest over. If a witchdoctor refuses to submit his items, he may be banned from the community or killed. As excommunication was not an option in this

26.Mutungi (1977:104) states that killing a witch "is not only approved but ... is also a praiseworthy service' in the eyes of many communities.

27.N. Jack, Jack Oral Archive (JOA), Interview with M.S., Block: Morosani, Platfontein, 30 June 2014:

Many of our good traditional healers stay in Namibia and we can't find them in South Africa. You have to take your family to that place if you want it, but it will cost you a lot of money.

N. Jack, Jack Oral Archive (JOA), Interview with B.K, Block: Morosani, Platfontein, 30 June 2014:

Today we don't have good traditional healers and when we take any problem to them, they help but it doesn't, it stays longer. The same problem comes back to the person.

N. Jack, Jack Oral Archive (JOA), Interview with R.K., Block: Morosani, Platfontein, 30 June 2014: 'They help many people but you have to pay them. If you don't pay them, it is not going to work'.

28.This is done in order to neutralise the sorcerer's powers. The river should not flow as this will spread the evil charms; also, care must be taken that people do not inhale the fumes of the fire into which the charms were cast (see Vorster 1994:77). 
community, the only choice was to have him publicly executed. ${ }^{29}$ The community, which included the deceased's two children, all agreed on this option. ${ }^{30}$

As can be seen from the examples provided above, witchcraft suspicions, accusations and practices are nurtured and maintained, more than anything else, by intra- and intercommunal conflict. This conflict is often intense and abiding in the community as it is built into the structure and chemistry of community 'politics'. Invidious feelings of rivalry and envy amongst the two groups have corroded most efforts towards collaboration in the community. The jealousy factor especially often tests, and even cripples, the development of local leadership in the community and development efforts. This witchcraft-generating conflict tends to be ongoing amongst members, 'not to be admitted to and thus pushed "underground" to fester and gain momentum, through brooding resentment and mounting anger' (Guenther 1992:93; Mayer 1982:54).

\section{Conflict prevention and conflict avoidance amongst the San}

It has been revealed by several researchers that in a society such as the San, conflict such as described above should not exist (Guenther 1992:89). This is because there are effective tension-releasing mechanisms constantly at work to cope with their differences. San children are taught by their elders to avoid disputes and to fear and avert violence. ${ }^{31}$ Traditionally, disputes are prevented by sharing resources, which includes the practice of gift exchange to foster amicable relations amongst the community members. Community norms such as respect for one another, especially for elders, are venerated. Incipient disputes are placated by gregarious and even playful acts which all members engage in to tend to each other's moods and demeanour. These mechanisms allow the primary actors in a dispute to save face, because the reproach is handled with discretion by one person or several persons about another, for instance, the 'forced eavesdrop' (Silberbauer 1982:26), where community members will reprimand someone within hearing distance by talking to others about the concern. Also, the mechanisms allow the San to vent their displeasure or hostility freely by means of talking, shouting, singing or even dancing. As Guenther (1992) proclaims:

In such spirited and extroverted fashion, feelings of anger, jealousy, or rivalry get aired; they are brought out in the open and become objectified, rather than being swept under the rug of sociability and repressed, to fester on, as 'unacted desires', accumulating rage and guilt. (p. 93)

29. He was then tied up with a chain and cables and suspended from a tree by his feet The chains pulled his upper arms together behind his back and were pulled tighter until he died. The reason why he was killed in this manner was to prevent any of his blood from being spilled on the ground where they lived which would have caused his evil powers to remain behind (see S v Mathoka 1992:443).

30.Approval was also obtained from a member of the San council, see Prinsloo (1993:335).

31.Ury (1995:380) relates a remark made to him by a San elder: 'The greatest lesson my father taught me was, "Never cause a problem so that it won't have to b settled. Live in harmony"'.' (see also Soskolne 2007:36).
Dancing is normally engaged in at the end of a potentially tense incident (Lee 1979:377), and is an especially effective mechanism of conflict prevention. As a creative form, it gives free expression to and consequent release of any repressed emotions. As such, dancing produces a swift and thorough pacification of anger or dissatisfaction in the context of an expressive social performance. Not only does dancing give expression to and manage hostility, but it is also a vehicle for criticising a member of the group and community healing (Guenther 1992:93).

A further method for expressing criticism and tension openly within the community is the joking relationship which is common within the San culture (Guenther 1992:93). There is seemingly a licence to tease amongst group members. This may be triggered by an individual who approaches another person - his partner-to-be in the jesting bout - to jokingly convey his ire or displeasure. Conflict prevention through mechanisms of this kind thwarts the conception of prolonged sentiments of malice, jealousy, hatred and revenge, 'the impulse to detract and spite - [conditions which are] so conducive to harbouring sinister suspicions of witchcraft or the desire to inflict the same' (Guenther 1992:93).

Conflict that cannot be controlled by means of these methods may culminate in violence. The San are a people who have traditionally been deeply uneasy about tension and strife, especially the kind that can lead to a killing (either outright or supernaturally). As such, conflict is avoided mainly by withdrawal from the conflict scene. The traditional approach of the San is consequently conflict avoidance, and if this is not possible, then to engage the other side on the basis of traditional wisdom that respect for nature should engender respect for others in conflict situations. The avoidance option is a highly effectual approach for constraining conflict: in instances where a quarrel grows too fierce or a stalemate is reached, one of the disputing parties departs to another place, settling with another group until all is forgotten (Guenther 1992:93). Withdrawing from one's antagonist may discontinue resentments as well as direct accusations and suspicions of witchcraft in the community.

Today, however, amongst the sedentary Platfontein San, withdrawal has essentially ceased to be an option. Thus, unable to remove themselves bodily from such dreaded conflict, the San has opted for community consultation as a means of conflict prevention with regard to inter-personal conflict. Yet accusations of witchcraft practices still persist, and consequently no lasting trust relationships are built amongst the two groups. Issues remain unsettled and tension and strife continue.

\section{Conclusion}

Lasting peace in the community requires that key actors have the skills and access to conflict prevention practices allowing them to cooperate across dividing lines, managing disputes through inclusive participation as well as open and honest communication. Conflict prevention at Platfontein has been 
reasonably successful in maintaining relative peace, but has not improved the conflict situation or strategies for conflict prevention and avoidance at all. In order to progressively reduce the underlying problems that produce their disputes, the two groups must build towards shared norm systems, which makes increased trust and understanding possible, and will finally result in the development of inter-communal cooperation and long-term relationships and interaction. However, mutually acceptable solutions to intra-communal conflict have not yet been found. The groups maintain to have been tolerant of each other for many years already, and have attempted to handle the conflict in ways that are more likely to produce constructive, rather than destructive, outcomes. Conflict-generating structures in the community such as witchcraft have been identified but conflict dynamics are still not altered at this stage.

The conflict between the !Xun and the Khwe has prompted some San members to openly voice a desire for separation. It has been suggested that Platfontein should be sold or liquidated so as to purchase separate locations for the two groups, thus ending any existing linkages between them (Robins et al. 2001:20; Soskolne 2007:24). Although it is the wish of some San to rather withdraw from Platfontein in order to build a new life elsewhere, it is hoped that with their shared history of dispossession, relocation and struggle, a common platform can be found to resolve their intercommunal tensions. To surmount the social tensions that might underlie the conflicts expressed in terms of witchcraft accusations, community mediation is certainly advocated. This traditional method of conflict resolution may promote peaceful and constructive management of their differences in order to create more positive communal relationships.

\section{Acknowledgements}

The author would like to extend a special thanks and appreciation to Dr AG Velthuizen, the project leader, all the Platfontein San field researchers, and especially the Platfontein San community for their assistance. Any opinion, findings and conclusions or recommendations expressed in this material are those of the author.

\section{Competing interests}

The author declares that she has no financial or personal relationships which may have inappropriately influenced her in writing this article.

\section{References}

Adhikari, M., 2010, 'A total extinction confidently hoped for: The destruction of Cape San society under Dutch colonial rule, 1700-1795', Journal of Genocide Research 12(1-2), 19-44. https://doi.org/10.1080/14623528.2010.508274

Ashforth, A., 2000, Madumo, a man bewitched, University of Chicago Press, Chicago, IL.

Ashforth, A., 2001, AIDS, witchcraft, and the problem of power in post-apartheid South Africa, Institute of Advanced Study, School of Social Science, Occasional Paper 10, Princeton, NJ.

Barnard, A., 2007, Anthropology and the Bushman, Berg, Oxford.

Becker, H., 2003, 'The least sexist society? Perspectives on gender, change and violence among Southern African San', Journal of Southern African Studies 29(1) 5-23. https://doi.org/10.1080/0305707032000060557
Beyene, H.G., 2014, 'Socio-economic factors as causes and remedies for conflict of the San community in Platfontein', The Journal for Transdisciplinary Research in Southern Africa 10(4), 99-119. https://doi.org/10.4102/td.v10i4.91

Boehm, C., 2000, 'Conflict and the evolution of social control', Journal of Consciousness Studies 7(1-2), 79-101.

Brain, J.L., 1982, 'Witchcraft and development', African Affairs 81, 371-384. https:// doi.org/10.1093/oxfordjournals.afraf.a097432

Carment, D. \& Schnabel, A., 2003, 'Introduction - Conflict prevention: A concept in search of a policy', in D. Carment \& A. Schnabel (eds.), Conflict prevention: Path to peace or grand illusion?, pp. 1-11, UN University Press, Tokyo.

Carnegie Commission on Preventing Deadly Conflict, 1997, Preventing deadly conflict: Final report, Carnegie Corporation, Washington, DC.

Evans-Pritchard, E.E., 1976, Witchcraft, oracles and magic among the Azande, Oxford University Press, Oxford.

Felton, S. \& Becker, H., 2001, A gender perspective on the status of the San in Southern Africa, Legal Assistance Centre, Windhoek.

Fry, D.P., 2007, Beyond war: The human potential for peace, Oxford University Press, New York.

Gluckman, M., 2012, Politics, law and ritual in tribal society, Transaction, New Brunswick.

Guenther, M.G., 1992, "Not a Bushman thing" Witchcraft among the Bushmen and hunter-gatherers', Anthropos 87, 83-107.

Guenther, M.G., 1999, Tricksters and trancers: Bushman religion and society, Indiana University Press, Bloomington, IN.

Hammond-Tooke, W., 1989, Rituals and medicines, AD Donker, Johannesburg.

Hitchcock, R.K., 2012, 'Refugees, resettlement, and land and resource conflicts: The politics of identity and !Xun and Khwe San in north-eastern Namibia', African Study Monographs 33(2), 73-132.

Isaacson, R., 2001, The healing land, Fourth Estate, London.

Köhler, O., 1978/1979, 'Mythus, glaube und magie bei den Kxoe-Buschmannern', Journal of the South West Africa Scientific Society 33, 9-50.

Lee, R.B., 1979, The !Kung San: Men, women and work in a foraging society, Cambridge University Press, Cambridge.

Lund, M.S., 2002, 'Preventing violent intrastate conflicts: Learning lessons from experience', in P. van Tongeren et al. (eds.), Searching for peace in Europe and Eurasia. An overview of conflict prevention and peacebuilding activities, pp. 99-122, Lynne Rienner Publishers, London.

Marwick, M. (ed.), 1982, Witchcraft and sorcery: Selected readings, Penguin, Middlesex.

Mayer, P., 1982, 'Witches', in M. Marwick (ed.), Witchcraft and sorcery: Selected readings, Penguin, Middlesex.

Munuera, G., 1994, Preventing armed conflict in Europe: Lessons learned from recent experience, Chaillot Paper 15/16, Institute for Security Studies, Alençon.

Mutungi, O.K., 1977, The legal aspects of witchcraft in East Africa with particular reference to Kenya, East African Literature Bureau, Nairobi.

Oatway, J., 2013, The lost crows, viewed 07 June 2017, from http://www.panos.co.uk/ preview/00166861.html?p=4

Parrinder, E.G., 1963, Witchcraft: European and African, Faber and Faber, London.

Prinsloo, M.W., 1993, 'Boesman-geloof in towery as strafversagtende faktor', Tydskrif vir die Suid-Afrikaanse Reg 2, 334-338.

Robins, S., Madzudzo, E. \& Brenzinger, M., 2001, An assessment of the status of the San in South Africa, Angola, Zambia and Zimbabwe, John Meinert Printing, Windhoek

S v Mathoka and Others 1992 (2) SACR 443 (NC).

San Dispute Resolution Oral Archive, viewed 07 June 2017, from http://uir.unisa. ac.za/handle/10500/13723

Sharp, J. \& Douglas, S., 1996, 'Prisoners of their reputation? The veterans of the 'Bushman' battalions in South Africa', in P. Skotnes (ed.), Miscast: Negotiating the presence of the Bushmen, pp. 323-329, University of Cape Town Press, Cape Town.

Shostak, M., 1981, Nisa. The life and words of a !Kung woman, Harvard Press, Cambridge, MA.

Silberbauer, G., 1982, 'Political process in G/wi bands', in E. Leacock \& R.B. Lee (eds.), Politics and history in band societies, pp. 23-36, Cambridge University Press, Cambridge.

Soskolne, T., 2007, "Being San" in Platfontein: Poverty, landscape, development and cultural heritage', MA dissertation, Dept. of Social Anthropology, University of Cape Town.

Steadman, L., 1985, 'The killing of witches', Oceania 56(2), 106-123. https://doi. org/10.1002/j.1834-4461.1985.tb02114.x

Swanström, L.P. \& Weissmann, M.S., 2005, Conflict, conflict prevention and conflict management and beyond: A conceptual exploration, Silk Road Studies, Uppsala.

Tanner, F., 2000, 'Conflict prevention and conflict resolution: Limits of multilateralism', International Review of the Red Cross 82(839), 541-559. https://doi.org/10.1017/ S1560775500184615 
Tebbe, N., 2007, 'Witchcraft and statecraft: Liberal democracy in Africa', The Georgetown Law Journal 96, 183-236.

UNESCO, 1982, Mexico declaration on cultural policies, UNESCO Publications, Paris

Ury, W.L., 1995, 'Conflict resolution among the Bushmen: Lessons in dispute systems design', Negotiation Journal 11(4), 379-389. https://doi.org/10.1111/j.1571-9979. 1995.tb00753.x

Uys, I., 2014, Bushmen soldiers, GG Books, Warwickshire.
Velthuizen, A.G., 2010, 'On truth-telling and storytelling: Truth-seeking during research involving communities with an oral culture and a history of violent conflict', The Journal for Transdisciplinary Research in Southern Africa 10(4), 19-35.

Vorster, L., 1994, 'Towery by die !Xu van Schmidtsdrift: 'n verklaring', SA Tydskrif vir Etnologie 17(3), 69-82.

Vorster, L., 1996, 'Konflik en konflikhantering by die !Xu en Khwe van Schmidtsdrift: ' $\mathrm{n}$ verkenning', Codicillus 37(2), 4-13. 